\title{
Plant vibration of american pepper cultivars for fruit production in protected environment with and without closed sides
}

\author{
Vibração de plantas de pimenta americana para produção de frutos em ambiente protegido
}

\author{
Pâmela Gomes Nakada Freitas ${ }^{\mathrm{I}}$ Felipe Oliveira Magro ${ }^{\mathrm{II}}$ Marina de Toledo Rodrigues Claudio ${ }^{\mathrm{II}}$ \\ Ana Emília Barbosa Tavares $^{I V}$ Antonio Ismael Inácio Cardosov ${ }^{\mathrm{V}}$ Natália de Brito Lima Lanna ${ }^{\mathrm{IV}}$
}

\section{ABSTRACT}

The aim of this research was to evaluate plant vibration for fruit and seed production of american pepper in greenhouse with open and closed sides. The experiment was carried out at Fazenda Experimental da Unesp/FCA located in the municipality of São Manuel-SP. Six treatments were carried out, in a split plot design, two plots with plant vibration or without plant vibration and three subplots with cultivars ('Dirce', 'Dinamo' and 'Doce Comprida'). Plants were vibrated by shaking the wire where the stake was fixed, manually, for about 5 seconds, twice a day. Randomized block design with three replications were used. The same experiment was performed in two environments: with and without closed sides with screen. The traits evaluated were: mass of fruit and total and marketable number of fruits (no visible defects) per plant; percentage of marketable fruit; mass, diameter and length of the fruit; mass and number of seeds per fruit; and plant height. The fruit production was higher in the environment with sides closed, with 24 marketable fruits per plant whereas in the open environment, 7 marketable fruits. American pepper plant vibration did not affect production, length, diameter and average mass of the fruits. Exceptionally for the cultivar 'Doce Comprida', a higher seed production per fruit was obtained in open environment in the absence of plant vibration, in comparison to close environment, with average of 259 and 126 seeds per fruit, respectively. American pepper plant vibration did not affect production, length, diameter and average mass of marketable fruits.

Key words: Capsicum annuum, fruiting, shaking of plants.

RESUMO

Objetivou-se verificar o efeito da vibração de plantas na produção de frutos e sementes de pimenta americana em cultivo protegido com laterais aberta e fechada. O experimento foi realizado na Fazenda Experimental da Unesp/FCA, localizada no municipio de São Manuel-SP. Foram seis tratamentos, em esquema de parcelas subdivididas, sendo as duas parcelas a vibração ou não das plantas e as subparcelas três cultivares de pimenta ('Dirce', 'Dínamo'e 'Doce Comprida'). As plantas foram vibradas balançando-se o arame onde se prendia o tutor de bambu com a mão por cerca de 5 segundos, duas vezes por dia. O delineamento foi em blocos ao acaso, com três repetições. O mesmo experimento foi realizado em dois ambientes: com e sem fechamento das laterais com tela. As características avaliadas foram: massa e número de frutos totais e comerciais (sem defeitos aparentes) por planta; porcentagem de frutos comerciais; massa, diâmetro e comprimento de fruto; massa e número de sementes por fruto; $e$ altura de planta. A produção de frutos foi maior no ambiente com as laterais fechadas, com 24 frutos comerciais por planta, enquanto, no ambiente aberto, foram sete. A vibração de plantas de pimentas americanas não afetou a produção, comprimento, diâmetro e massa média de frutos. Apenas para a cultivar 'Doce Comprida' obteve-se maior produção de sementes por fruto no ambiente aberto em relação ao ambiente fechado, na ausência de vibração das plantas, com média de 259 e 126 sementes por fruto, respectivamente. A vibração de plantas de pimentas americanas não afetou a produção, comprimento, diâmetro e massa média de frutos comerciais.

Palavras-chave: Capsicum annuum, polinização, inseto polinizador, movimentação de plantas.

\section{INTRODUCTION}

American pepper is the same species of sweet pepper: Capsicum annuum. This pepper is adapted to tropical region, and does not tolerate low temperatures and excessive rainfall. Protected

\footnotetext{
'Faculdades Gammon, Rua Prefeito Jayme Monteiro, 791, Centro, 19700-000, Paraguaçu Paulista, SP, Brasil. E-mail: pamnakada@yahoo.com.br. Corresponding author.

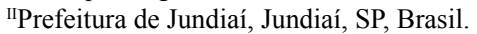

IIISakataSeedSudamerica, Bragança Paulista, SP, Brasil.

IV Departamento de Produção Vegetal, Faculdade de Ciências Agrárias, Universidade Estadual Paulista (UNESP), Botucatu, SP, Brasil.
} 
environment is the best option for cultivation, favoring higher production per hectare. The sides of this environment are tipically closed with screens in order to avoid insect pests, but it is also a major obstacle to pollinators.

The species of genus Capsicum are autogamous and they have perfect flowers, having male and female structures in the same flower, which facilitates reproduction by self- pollination. Although these species are classified as autogamous, some genotypes present allogamy rate which ranges from 2 to $90 \%$ (BOSLAND \& VOTAVA, 2000), and some studies show benefits of pollinators presence (CRUZ et al., 2005; SERRANO \& GUERRA-SANZ, 2006; NASCIMENTO et al., 2012).

For sweet pepper, CRUZ et al. (2005) reported the influence of stingless bee Melipona subnitida in order to pollinate, contributing to the production of heavier fruits, with higher diameter, greater number of seeds and lower percentage of malformed fruits when compared to self-pollinated crops. The authors believe that the presence of these insects contribute to greater pollen supply, increasing the number of embryos and favoring the fruit development.

NUNES-SILVA et al. (2010), describes buzz pollination as: bees land on the anthers, bend, grab tightly, which contract the chest muscles, promoting vibrations, causing resonance within the anthers and releasing pollen. RAW (2000) emphasizes that the bee vibration is very important for Solanaceae species, such as tomato, eggplant, jilo, peppers and sweet peppers.

In order to promote a similar effect to that of the bees, some authors have carried out studies on manual vibration in an attempt to increase production. When vibrating racemes of tomato, they verified an increase in the production when comparing to the control without vibration (SATTI, 1986; ILBI \& BOZTOK, 1994). Increases in productivity were also found by HIGUTI et al. (2010) in tomato with plant vibration. However, CARDOSO (2007), did not obtain an increase in production for sweet pepper with plant vibration in environment without pollinators. Studying different pollinators and mechanical vibration in tomato, we found an increase in fruit production in the presence of insects, being higher than the mechanical vibration treatment (PALMA et al., 2008).

It is functional and simple technology technique that resulted in an increase in productivity for tomato crop, which has already been used by growers. For peppers, no results on plant vibration were found. Therefore, the aim of this research was to verify the effect of plant vibration on fruit and seed production of American pepper cultivars in greenhouse with open and closed sides.

\section{MATERIAL AND METHODS}

The experiment was carried out at the Experimental Farm São Manuel, belonging to Faculdade de Ciências Agronômicas (FCA) of the Universidade Estadual Paulista (UNESP), Botucatu Campus, located in the municipality of São Manuel, São Paulo State, Brazil.

Two arch-type greenhouses were used, with dimensions of $7 \times 20 \mathrm{~m}$ and $2.5 \mathrm{~m}$ ceiling height, covered with transparent polyethylene of low density (LDPE), $150 \mu \mathrm{m}$ thickness; one greenhouse remaining with open sides and the other one with sides closed with aphid-proof screen during the cycle, avoiding the entrance of pollinators.

Pepper seedlings were grown in polystyrene trays with 162 cells. Sowing was carried out on August $16^{\text {th }}$ and the seedlings were transplanted on October $5^{\text {th }}, 2011$ when they showed five definitive leaves, in seedbeds of $0.3 \mathrm{~m}$ wide, spacing $1.0 \mathrm{~m}$ between lines and $0.5 \mathrm{~m}$ between plants.

The soil presented the following characteristics: $\mathrm{pH}_{(\mathrm{CaCl} 2)}=5.3 ; \mathrm{P}_{\text {resina }}=146 \mathrm{mg} \mathrm{dm}^{-3}$; organic matter $=23 \mathrm{~g} \mathrm{dm}^{-3} ; \mathrm{V}=75 \%$; and values of $\mathrm{H}+\mathrm{Al} ; \mathrm{K} ; \mathrm{Ca} ; \mathrm{Mg}$; $\mathrm{SB}$ and $\mathrm{CEC}$, expressed in $\mathrm{mmol}_{\mathrm{c}}$ $\mathrm{dm}^{-3}$, of $32 ; 3.8 ; 79 ; 8 ; 91$ and 123 , respectively. Liming was not necessary, $\mathrm{K}$ and $\mathrm{P}$ contents were considered high. Planting fertilization and top dressing were performed according to the recommendation of boletim 100 (RAIJ et al., 1996).

Six treatments were carried out, in a split plot design, two plots with plant vibration or without plant vibration and three subplots with pepper cultivars ('Dirce', 'Dínamo' and 'Doce Comprida'), all of them american peppers.

Randomized block design with three replications was used. Each subplot was consisted of five plants, considering the three center ones as useful. The same experiment was performed in two mentioned environments: with and without closed sides with aphid-proof screen.

Staking was performed with the help of bamboo canes, individually and independently per plot, in order to avoid interference of one plot with vibration on the other one without vibration. Plant vibration treatment began right after the opening of the first flower, on November 28, 2011, vibrating, manually, the wire where the bamboo cane was 
fixed, for about 5 seconds, twice a day, early in the morning (at 7am) and in the evening (at $5 \mathrm{pm}$ ), until February $17^{\text {th }}, 2012$, totaling 12 weeks of treatment. This vibration aims to release more pollen and it was adopted according to the methodology proposed by CARDOSO (2007) for sweet pepper and by HIGUTI et al. (2010) for tomato.

The cultural practices held were: sprout thinning until the appearance of the first flower, located at the first fork; removing of this first flower; hand weeding, when necessary; staking of the plants; dripping irrigation and application of fungicides in the control of powdery mildew (Oidiopsis taurica). Harvestings were performed weekly from January $3^{\text {rd }}, 2012$, up to February $27^{\text {th }}, 2012$. The harvesting time was when the fruits began to change the color from green to red.

The traits evaluated were: mass production (g) and total and marketable number of fruits per plant (standard size of the cultivar and straight fruits); percentage of marketable fruit (obtained through relation between marketable and total number of fruits produced per plant); average mass of marketable fruit; diameter and length of marketable fruit (measurement obtained using digital caliper, of all marketable fruit, from all harvestings, with subsequent calculation of the average); mass and number of seeds per fruit and plant height (obtained at the end of the cycle, using a measuring tape). To obtain seed number and mass, one marketable fruit per harvesting, per subplot,was sampled, which remained at rest for a week before seed extraction. Afterwards, these seeds remained in a dry chamber $\left(20^{\circ} \mathrm{C}\right.$ and $\left.40 \% \mathrm{RH}\right)$ to uniform water content of approximately $8 \%$ and then to perform weighting.

The data obtained were subjected to analysis of variance and the averages were compared by Tukey test $5 \%$. In order to compare the environments, joint analysis was performed, considering each environment as an experiment, according norms described by BANZATTO \& KRONKA (2006).

\section{RESULTS AND DISCUSSION}

No significant effect was noticed for plant vibration and for interactions involving vibration, cultivars and environments for all traits, except for number of seeds per fruit and percentage of marketable fruit, allowing comparison and discussion on cultivars and environments, separately, for other traits.

The authors observed greater number of total and marketable fruits for cultivar 'Doce Comprida', although no significant difference was noticed for total number of fruit in relation to 'Dirce', nevertheless 'Doce Comprida' was 3.7 fruits superior (Table 1). It is noteworthy that 'Dirce' and 'Dínamo' are hybrids and 'Doce Comprida' is an open-pollinated cultivar. Typically, hybrids are recognized for high yield potential, precocity, plant vigor, uniformity of production and disease resistance (MALUF, 2001).

As for fruit traits, diameter was higher for cultivars 'Doce Comprida' and 'Dínamo', whereas the highest fruit length was observed for 'Dínamo' and 'Dirce' (Table 1). Probably these characteristics are inherent for each cultivar. According to the description of holding companies, 'Dirce' is 200$220 \mathrm{~mm}$ long and 'Doce Comprida' is $120 \mathrm{~mm}$ long and $40 \mathrm{~mm}$ in diameter. Thus, for 'Doce Comprida', we obtained fruit with superior dimensions than those described, indicating good performance of this cultivar in these environments. In relation to fruit mass, no significant difference was noticed, for any source of variation, with general average of $90.2 \mathrm{~g}$ per fruit, as well as for marketable and total production characteristics per plant and plant height (Table 1), characterizing similar potential of the evaluated materials.

Higher values for number and mass of marketable and total fruit per plant were obtained in closed environment (Table 2). It was noticed that production in this environment was approximately three times higher than in open environment. This lower production is justified, probably, due to two

Table 1 - Number of marketable (NFC) and total fruits per plant (NFT), diameter (DFC) and length of marketable fruits (CFC), mass of marketable fruits (MFCP) and total fruits (MFTP) per plant and plant height (AP), of American pepper cultivars.

\begin{tabular}{lllccccc}
\hline Cultivar & NFC & NFT & DFC (mm) & CFC (mm) & MFCP (g) & MFTP (g) & AP (cm) \\
\hline 'Dirce' & $14,2 \mathrm{~b} *$ & $16,5 \mathrm{ab}$ & $41 \mathrm{~b}$ & $204 \mathrm{a}$ & $1358 \mathrm{a}$ & $1539 \mathrm{a}$ & $112,4 \mathrm{a}$ \\
'Dínamo' & $14,6 \mathrm{~b}$ & $16,4 \mathrm{~b}$ & $49 \mathrm{a}$ & $205 \mathrm{a}$ & $1372 \mathrm{a}$ & $1526 \mathrm{a}$ & $94,0 \mathrm{a}$ \\
'DoceComprida' & $18,9 \mathrm{a}$ & $20,2 \mathrm{a}$ & $48 \mathrm{a}$ & $164 \mathrm{~b}$ & $1620 \mathrm{a}$ & $1696 \mathrm{a}$ & $105,8 \mathrm{a}$ \\
CV $(\%)$ & 18,4 & 14,2 & 5,9 & 4,7 & 18,9 & 16,5 \\
\hline
\end{tabular}

*Means followed by the same lowercase letter in column are not different (Tukey 5\%). 
Table 2 - Number of marketable (NFC) and total fruits per plant (NFT) marketable fruit mass (MFCP) and total fruit mass per plant (MFTP) and plant height (AP) of american pepper under environment with open and closed sides.

\begin{tabular}{|c|c|c|c|c|c|}
\hline Sides & NFC & NFT & $\operatorname{MFCP}\left(\mathrm{g}_{\text {plant }}{ }^{-1}\right)$ & $\operatorname{MFTP}\left(\mathrm{g}_{\text {plant }}{ }^{-1}\right)$ & $\mathrm{AP}(\mathrm{cm})$ \\
\hline Open & $7,3 b^{*}$ & $8,3 \mathrm{~b}$ & $658 \mathrm{~b}$ & $720 \mathrm{~b}$ & $84,4 \mathrm{~b}$ \\
\hline Closed & $24,5 \mathrm{a}$ & $27,2 \mathrm{a}$ & $2242 \mathrm{a}$ & $2454 \mathrm{a}$ & $123,8 \mathrm{a}$ \\
\hline $\mathrm{CV}(\%)$ & 24,8 & 24,7 & 41,6 & 42,3 & 14,0 \\
\hline
\end{tabular}

*Means followed by the same lowercase letters in column are not different (Tukey 5\%).

reasons: because of rains and higher incidence of disease. Due to the open sides, rainwater entered the greenhouse without screen, even when with little wind, resulting in waterlogged soil, wetting the plants and, because of the wind, greater dispersion of powdery mildew spores ( $\boldsymbol{O}$. taurica) was noticed, which settled over the cycle, hindering the development of the plants in the open environment.

This pathogen is a fungus which has been considered the most problematic disease which attacks pepper and sweet pepper crops in greenhouse conditions in Brazil (BLAT et al., 2005). Mild temperatures and higher moisture in the environment are favorable for disease development. In an open side environment, minimum and maximum temperatures of 17 and $34^{\circ} \mathrm{C}$ occurred, whereas with sides closed with screen, 20 and $40^{\circ} \mathrm{C}$. Besides presenting lower plants, open environment (Table 2) showed defoliation, causing direct effects on production.

The production in this experiment was satisfactory, high values were verified both in fruit number and mass, mainly in an environment with closed sides (Table 2). No studies on this kind of pepper were found, thus comparing with other studies on sweet pepper in a protected environment, production was not different. CARDOSO (2007) obtained average production of 13 fruits and mass of 2,726g of fruits per plant, whereas in this experiment for sweet pepper production, the values were 24 fruits and mass of 2,242g per plant. ARAÚJO et al.(2009) reported maximum number of marketable fruits per plant of 12.8 , with average mass of $80 \mathrm{~g}$. RODRIGUES et al. (2007) reported up to 37 fruits per plant. Although all of the cited studies had been carried out in a protected environment, places/weather conditions and cultivars were different, besides harvesting time. In this study, despite the american pepper fruit has smaller mass compared with most sweet peppers, the plants showed high production capacity, even harvesting ripe fruit, which can reduce new fruit set in the plant due to the fact that this is a more demanding sink than the ripe fruit (BOSLAND \& VOTAVA, 2000).

Greater number of seeds per fruit was obtained for cultivar 'Doce Comprida' in relation to 'Dínamo' only in open environment, in the absence of plant vibration (Table 3). For cultivar 'Doce

Table 3 - Number (NSF) and mass of seeds per fruit (MSF) and percentage of marketable fruits (FC) of American pepper cultivars depending on cultivation under environment with open or closed sides and plant shaking.

\begin{tabular}{|c|c|c|c|c|c|c|}
\hline \multirow[t]{2}{*}{ Cultivares } & \multicolumn{2}{|c|}{-------- Environment with sides -------- } & \multicolumn{2}{|c|}{----- Environment with sides -------- } & \multicolumn{2}{|c|}{---- Environment with sides -------- } \\
\hline & Open & Closed & Open & Closed & Open & Closed \\
\hline & \multicolumn{6}{|c|}{ 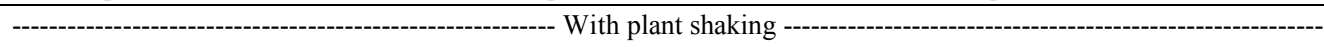 } \\
\hline 'Dirce' & $150 \mathrm{Aa}^{*}$ & $151 \mathrm{Aa}$ & $1,18 \mathrm{Aa}$ & $1,07 \mathrm{Aa}$ & $74,3 \mathrm{Bb}$ & $89,0 \mathrm{Aa}$ \\
\hline ‘Dínamo’ & $166 \mathrm{Aa}$ & $111 \mathrm{Aa}$ & $1,28 \mathrm{Aa}$ & $0,81 \mathrm{Aa}$ & $88,0 \mathrm{Aab}$ & $92,2 \mathrm{Aa}$ \\
\hline \multirow[t]{2}{*}{ 'Doce Comprida' } & 244 Aa & $191 \mathrm{Aa}$ & $1,53 \mathrm{Aa}$ & $1,15 \mathrm{Aa}$ & 92,9 Aa & 95,9 Aa \\
\hline & & & --- With & shaking --- & 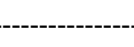 & 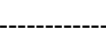 \\
\hline 'Dirce' & $177 \mathrm{Aab}$ & $164 \mathrm{Aa}$ & $1,23 \mathrm{Aa}$ & $1,03 \mathrm{Aa}$ & $91,3 \mathrm{Aa}$ & $84,6 \mathrm{Aa}$ \\
\hline 'Dínamo' & $125 \mathrm{Ab}$ & $107 \mathrm{Aa}$ & $0,93 \mathrm{Aa}$ & 0,79 Aa & $92,6 \mathrm{Aa}$ & $85,7 \mathrm{Aa}$ \\
\hline 'Doce Comprida' & $259 \mathrm{Aa}$ & $126 \mathrm{Ba}$ & $1,55 \mathrm{Aa}$ & $0,80 \mathrm{Ba}$ & $87,5 \mathrm{Aa}$ & $90,8 \mathrm{Aa}$ \\
\hline $\mathrm{CV}(\%)$ & \multicolumn{2}{|c|}{35,8} & \multicolumn{2}{|c|}{35,9} & \multicolumn{2}{|c|}{8,4} \\
\hline
\end{tabular}

*Means followed by the same lowercase letter in column are not different (Tukey 5\%). 
Comprida', higher mass and greater number of seeds per fruit in an open environment comparing to the environment with closed sides was noticed, whereas for 'Dirce' and 'Dínamo' differences between the environments were not observed. A possible explanation for this fact is the presence of pollinators in the environment with open sides, according to what was reported by CRUZ et al. (2005), SERRANO \& GUERRA-SANZ (2006) and NASCIMENTO et al. (2012).

However, when plant vibration was performed, we observed no significant effect between cultivars and between the environments in relation to number of seeds per fruit (Table 3). Perhaps vibration might have favored, in small quantity, release of pollen, mainly for cultivar 'Doce Comprida', greater seed formation equalizing the treatments which had produced fewer seeds compared to the treatments which produced more seeds in the absence of vibration. An increase in tomato fruit production both with vibration as with the presence of pollinators was reported, with more pronounced effect to the pollinators (PALMA et al., 2008). Besides these factors, in environment with open sides, plants may also have been benefited by the wind which is able to vibrate the plants.

For sweet pepper, CARDOSO (2007) did not obtain an increase in production with plant vibration either, differently from what was reported by several authors for tomato (SATTI, 1986; ILBI\&BOSTOK, 1994; HIGUTI et al., 2010). According to NUEZ (2001), the existence of perfect anther cones in tomato favors the effect of vibration with higher ovule fertilization and seed and fruit formation.

Despite the difference in the number of seeds observed, with higher value for 'Doce Comprida' in open environment with vibration in relation to 'Dínamo', no difference for average of fruit mass was observed, with general average of $90.2 \mathrm{~g}$. For tomato and sweet pepper, fruit size was reported as positively correlated with seed number (KHAH \& PASSAM, 1992; NUEZ, 2001; KINET \& PEET, 2002; HIGUTI et al., 2010). Perhaps the reason is the fact that only the commercial fruit, larger and without deformation, had been evaluated for mass, length and diameter, disregarding the small and defective fruit. In addition, according to MARCELIS \& HOFMANEIJER (1997), the effect of number of seeds on fruit size and mass, for sweet pepper, only manifests itself when the number of seeds is low number of seeds lower than 100). When it is great (greater than 100 seeds) this effect is not manifested. Thus, a supplementary pollination will only have an effect on fruit size if the number of seeds formed without this complement is small (less than 100 seeds), which was not the case in this experiment (Table 3 ).

Higher percentage of marketable fruit for 'Doce Comprida' than for 'Dirce' only with plant vibration in an open side environment was observed (Table 3). The authors believe that higher value of number of seeds per fruit for cultivar 'Doce Comprida' may have contributed to lower rate of defective fruit. KINET \& PEET (2002) reported that the formation of small and defective fruit may occur because of pollination failures, and, due to open sides, pollinators could enter the environment complementing pollination and seed formation for the open-pollinated cultivar ('Doce Comprida'). However, even in the worst treatment, percentage of marketable fruit was high (74.3\%) (Table 3 ) probably due to high quantity of seeds per fruit in all treatments, for all cultivars and vibration management, resulting in large and well formed fruits, sometimes with larger dimensions than those described in the catalogs of the companies which market them.

\section{CONCLUSION}

The fruit production was higher in the environment with sides closed. Mechanic plant vibration of american pepper did not affect the production, length, diameter and average mass of marketable fruits. Highest seed production per fruit was obtained in an open environment, in the absence of plant vibration, for cultivar 'Doce Comprida'.

\section{ACKNOWLEDGMENT}

To Coordenação para o Aperfeiçoamento de Pessoal de Nível Superior (CAPES) for the scholarships granted for the postgraduation students of the Departamento de Horticultura - Faculdade de Ciências Agronômica/Universidade Estadual Paulista (UNESP).

\section{REFERENCES}

ARAÚJO,J.S. etal.Cultivodopimentão em condições protegidas sob diferentes doses de nitrogênio via fertirrigação. Revista Brasileira Engenharia Agrícola e Ambiental, v.13, n.5, p.559-565, 2009. Available from: $<$ http://www.scielo.br/scielo.php?script=sci_artte xt\&pid=S1415-43662009000500008>. Accessed: May 08, 2015. doi: $10.1590 / \mathrm{S} 1415-43662009000500008$.

BANZATTO, D.A.; KRONKA, S.N. Experimentação Agrícola. 4.ed. Jaboticabal: FUNEP, 2006. 237p.

BLAT, S.F. et al. Reação de acessos de pimentão e pimentas ao oídio (Oidiopsis taurica). Horticultura Brasileira, v.23, n.1, p.72-75, 2005. Available from: $<$ http://www.scielo.br/scielo.php?script=sci arttext\&pid=S0102-05362005000100015 $>$. Accessed: May 08, 2015. doi: 10.1590/S0102-05362005000100015. 
BOSLAND, P.W.; VOTAVA, E.J. Peppers: vegetable and spice capsicums.Wallingford: CABI, 2000.204p.

CARDOSO, A.I.I. Efeito da vibração das plantas na produção de pimentão. Ciência e Agrotecnologia, v.31, n.4, p.1061-1066, 2007. Available from: <http://www.scielo.br/scielo.php?script=sci_artte xt\&pid=S1413-70542007000400018> . Accessed: May 08, 2015. doi: $10.1590 / \mathrm{S} 1413-70542007000400018$

CRUZ, D.O. et al. Pollination efficiency of the stingless bee Melipona subnitida on greenhouse sweet pepper. Pesquisa Agropecuária Brasileira, v.40, n.12, p. 1197-1201, 2005. Available from: <http://www.scielo.br/scielo.php?pid=s0100$204 \times 2005001200006 \&$ script $=$ sci arttext $>$. Accessed: May 08, 2015. doi: 10.1590/S0100-204X2005001200006.

HIGUTI, A.R.O. et al. Produção de tomate em função da "vibração" das plantas. Bragantia, v.69, n.1, p.87-92. 2010 Available from: <http://www.scielo.br/scielo.php?pid=S0006$87052010000100012 \&$ script $=$ sci arttext $>$. Accessed: May 08, 2015. doi: 10.1590/S0006-87052010000100012.

ILBI, H.; BOZTOK, K. The effects of different truss-vibration durations on pollination and fruit set of greenhouse grown tomatoes. Acta Horticulturae, n.366, p.73-78, 1994. Available from: <http://www.actahort.org/books/366/366_6.htm>. Accessed: May 08, 2015.

KHAH, E.M.; PASSAM, H.C. Flowering, fruit set and development of the fruit and seed of sweet pepper cultivated under conditions of high ambient temperature. Journal of Horticultural Science, v.67, p. 251-258, 1992. Available from: <http://www.jhortscib.org/ Vol67/67_2/14.htm>. Accessed: May 08, 2015.

KINET, J.M.; PEET, M.M. Tomato. In: WIEN, H.C. (Ed.). The physiology of vegetable crops. Wallingford: CABI Publishing, 2002. Chap. 6, p.207-258.

MALUF, W.R. Heterose e emprego de híbridos $\mathrm{F}_{1}$ em hortaliças. In: NASS, L.L.et al. (Eds.). Recursos genéticos e melhoramento: plantas. Rondonópolis: Fundação MT, 2001.p. 327-356.

MARCELIS, L.F.M.; HOFMAN-EIJER, L.R.B. Effects of seed number on competition and dominance among fruits in Capsicum annuum L. Annals of Botany, v.79, p. 687-693,1997. Available from: <http://www.researchgate.net/publication/31010395_Effects of_Seed_Number_on_Competition_and_Dominance_among Fruits_in_Capsicum_annuum_L>.Accessed: May 08, 2015.

NASCIMENTO, W.M. et al. Utilização de agentes polinizadores na produção de sementes de cenoura e pimenta doce em cultivo protegido. Horticultura Brasileira, v.30, n.3, p. 494-498,
2012. Available from: <https://www.google.com/url?sa=t\&rct $=\mathrm{j} \& \mathrm{q}=\&$ esrc $=\mathrm{s} \&$ source $=\mathrm{web} \& \mathrm{~cd}=1 \& \mathrm{cad}=\mathrm{rja} \&$ uact $=8 \& \mathrm{ved}=0$ CBwQFjAA\&url=http\%3A\%2F\%2Fwww.scielo.br\%2Fscielo. php\%3Fpid\%3DS0102-05362012000300023\%26script\%3Dsci arttext\&ei=khVNVcHoH8zYggS254HoBQ\&usg=AFQjCNEDIUi qb9mx9-30E7e2uomyUCpwFg>. Accessed: May 08, 2015.

NUEZ, F. El cultivo del tomate. Madrid: Mundi Prensa, 2001. 793p.

NUNES-SILVA, P. et al. A polinização por vibração. Oecologia Australis, v.14, n.1, p.140-151,2010. Available from: <http:// www.oecologiaaustralis.org/ojs/index.php/oa/article/view/ oeco.2010.1401.07>. Accessed: May 08, 2015. doi: 10.4257/ oeco.2010.1401.07.

PALMA, G. et al. Production of greenhouse tomatoes (Lycopersicon esculentum) using Nannotrigona perilampoides, Bombus impatiens and mechanical vibration. Journal of Applied Entomology, v.132, p.79-85, 2008. Available from: <http:// onlinelibrary.wiley.com/doi/10.1111/j.1439-0418.2007.01246.x/ abstract $>$. Accessed: May 08, 2015. doi: 10.1111/j.14390418.2007.01246.x

RAIJ, B.Van. et al. Recomendações de adubação e calagem para o Estado de São Paulo. Campinas: Instituto Agronômico \& Fundação IAC, 1996. 285p.

RAW, A. Foraging behaviour of wild bees at hot pepper flowers (Capsicum annuum) and its possible influence on cross pollination. Annals of Botany, v.85, p.487-492, 2000. Available from: $<$ http:// aob.oxfordjournals.org/content/85/4/487>. Accessed: May 08, 2015. doi: 10.1006/anbo.1999.1090.

RODRIGUES, I.N. et al. Produção e qualidade de frutos de híbridos de pimentão (Capsicum annuum) em ambiente protegido em Manaus-AM. Acta Amazônica, v.37, n.4, p.491-495, 2007. Available from: <http://www.scielo.br/scielo.php?script=sci_artte xt\&pid=S0044-59672007000400002>. Accessed: May 08, 2015. doi: 10.1590/S0044-59672007000400002.

SATTI, S.M.E. Artificial vibration for increasing fruit set of tomato under arid conditions. Acta Horticulturae, n.190, p. 455-457, 1986. Available from: <http://www.actahort.org/ books/190/190 51.htm>. Accessed: May 08, 2015.

SERRANO, A.R.; GUERRA-SANZ, J.M. Quality fruit improvement in sweet pepper culture by bumble bee pollination. Scientia Horticulturae, v.110, p. 160-166, 2006. Available from: <http://www.sciencedirect.com/science/article/pii/ S030442380600272X>. Accessed: May 08, 2015. doi: $10.1016 / \mathrm{j}$. scienta.2006.06.024. 